\title{
Transformation of resource management institutions under globalization: the case of songgye community forests in South Korea.
}

\author{
$\underline{\text { David J. Yu }}^{1,2}, \underline{\text { John M. Anderies }}^{1,2,3}$. Dowon Lee $^{4}$ and Irene Perez $^{2}$
}

\begin{abstract}
The context in which many self-governed commons systems operate will likely be significantly altered as globalization processes play out over the next few decades. Such dramatic changes will induce some systems to fail and subsequently to be transformed, rather than merely adapt. Despite this possibility, research on globalization-induced transformations of social-ecological systems (SESs) is still underdeveloped. We seek to help fill this gap by exploring some patterns of transformation in SESs and the question of what factors help explain the persistence of cooperation in the use of common-pool resources through transformative change. Through the analysis of 89 forest commons in South Korea that experienced such transformations, we found that there are two broad types of transformation, cooperative and noncooperative. We also found that two system-level properties, transaction costs associated group size and network diversity, may affect the direction of transformation. SESs with smaller group sizes and higher network diversity may better organize cooperative transformations when the existing system becomes untenable.
\end{abstract}

Key Words: collective action; community-based forest management; forest commons; multilevel governance; nested enterprise; network diversity; robustness; robustness trade-offs; social-ecological systems; songgye; transformative capacity of social-ecological systems

\section{INTRODUCTION}

Studies of commons dilemmas have often focused on investigating factors that affect whether and how institutions succeed or fail in enabling collective action in social-ecological systems (SESs; Ostrom 1990, 2005, Ostrom et al. 2002). This work has typically been static in nature: the biophysical, social, economic, and institutional factors that define the context in which the agents interact are assumed fixed. Recently, scholars have begun to view commons dilemmas through a dynamic lens, and to focus on what factors affect the capacity of SESs to cope with change. One way SESs cope with change is through transformation, a process that occurs when ecological, economic, or social structures make the existing system untenable and a fundamentally new system is created in response (Walker et al. 2004).

We build on the foundation described above to explore transformation patterns of SESs. We focus on the question of what factors help explain the persistence of effective collective action in the management of common-pool resources in SESs under conditions that will likely be realized in the next few decades as a result of globalization. Specifically, scholars suggest that globalization will connect SESs across multiple temporal and spatial scales, dramatically changing the context in which many self-governed common-pool resource (CPR) institutions operate (Young et al. 2006, Anderies and Janssen 2011). One of the ways that such global interconnectedness can impact local selfgoverned CPR systems is by increasing the inflow of substitute goods for CPRs or increasing the opportunity cost of labor, which will reduce the salience of CPRs for local livelihoods (Poteete and Ostrom 2004, Araral 2009). Such changes in context will likely induce some self-governed systems to fail and subsequently transform themselves, rather than merely adapt. In the process, social actors will likely be confronted with dilemmas linked to the release and reorganization of their natural capital. Some actors may prefer the immediate benefit of selling out natural capital and taking their share of the proceeds over the uncertain long- term benefit of maintaining cooperation in some alternative ways. Systematic research on the postfailure transformation process is rare in the commons literature (although see Abel et al. 2006), and the connection between different transformation paths and their determinants remains poorly understood (Rudel 2011).

In the literature, there are a number of studies that explore the reorganization of SESs in a different light. For example, several case studies investigate the struggles of local SESs subjected to novel disturbances, such as increased market pressure (Wunder et al. 2008, Silva et al. 2010), flows of people or intruders (Pérez et al. 2011), and development (Wollenberg et al. 2006, Levang et al. 2007). These studies focus on particular aspects of disturbances and ensuing responses themselves, rather than on the details of transformation. In another set of studies, scholars exclusively analyze transformations (Olsson et al. 2004, Biggs et al. 2010, Gelcich et al. 2010). These studies, however, either do not involve CPRs or rely heavily on small-N cases related to very specific contexts. A single-case study or small-N set of case studies can have rich insights about a particular setting, but their findings cannot easily translate into a broader theoretical analysis (Basurto and Ostrom 2009). Finally, some studies approach the subject from the perspective of long-term vulnerability and transformation (Anderies 2006, Nelson et al. 2010). These studies rely on a small-N set of archeological cases, populated with very coarse data, and they focus on aspects of hidden vulnerabilities that emerge when SESs optimize for a particular set of disturbances.

Our research complements the existing literature by examining 89 forest commons in the Geumsan region (Fig. 1) of South Korea (Kang 2001). After persisting for hundreds of years, these selfgoverned SESs all collapsed and underwent major transformations, e.g., conservation of natural capital, conversion to new community infrastructure, and selling out, in the second half of the 20th century as South Korea developed economically.

${ }^{1}$ School of Sustainability, Arizona State University, ${ }^{2}$ Center for the Study of Institutional Diversity, Arizona State University, ${ }^{3}$ School of Human Evolution and Social Change, Arizona State University, ${ }^{4}$ Graduate School of Environmental Studies, Seoul National University 
The major drivers of this change include: (1) the transition in the nation's primary energy consumption from high dependence on forest resources to near-zero dependence; (2) the massive ruralurban migration, driven by the search for better opportunities; and (3) the introduction of national-level forestation policies (Fig. 2 ). Because this set of cases constitutes a relatively large- $\mathrm{N}$ dataset and provides accounts of a range of different transformations under globalization, a careful analysis may yield some general insights on transformative capacity of SESs.

Fig. 1. Map of Geumsan, South Korea. Light yellow area in the magnified map indicates the terrains of flat and lower slopes and roughly approximates the flat valleys. Green area indicates the mountainous terrains. The letters $\mathrm{A}$ to $\mathrm{J}$ in the magnified map indicate 10 administrative districts of Geumsan.

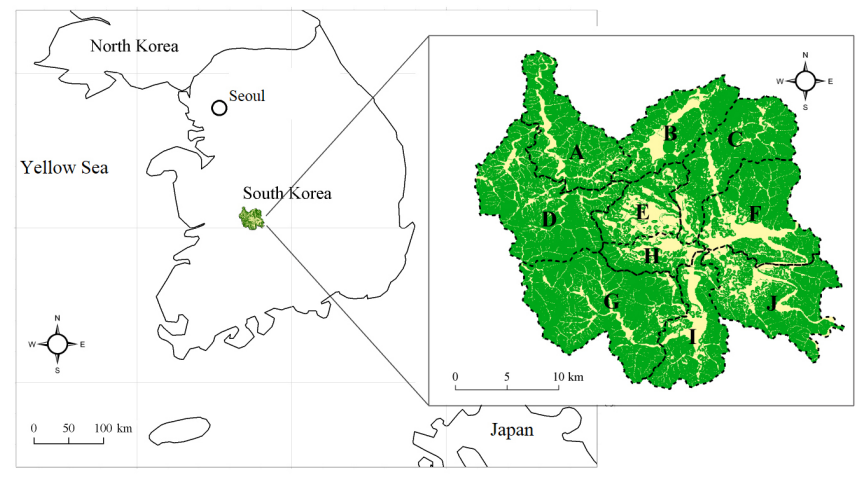

In this paper, we tackle three research questions. First, what are the patterns of transformation undergone by the 89 self-governed systems? Unlike what is indicated by the dichotomous classification of SESs as either robust or collapsed (Anderies et al. 2004), transformations can involve multiple trajectories of change. Second, what are some of the key factors that influence the persistence of effective collective action in the management of shared resources as systems undergo transformative change? We focus on the less-investigated effects of system-level structures, e.g., network diversity and transaction costs, rather than on the details of community interactions that are often emphasized in small-N case studies. Third, are there trade-offs between optimizing to particular past conditions and transformative capacity (sensu Janssen et al. 2007)? Here, we investigate whether self-governed SESs that may have become robust to particular past conditions undergo less cooperative transformations when they face new challenges in this era of globalization.

\section{METHODS}

\section{The study system}

The Geumsan region sits in the central inland area of South Korea and encompasses $576 \mathrm{~km}^{2}$. The landscape of the region is roughly characterized by a large central flat valley and surrounding mountain ranges with forests (Fig. 1). Hundreds of villages are interspersed throughout the area. Songgye (pronounced "songgeh") are traditional Korean forest organizations, established for setting up community-owned mountainous forests to provide access to firewood and organic compost made from weedy plants growing inside forests (Kang 2001, Chun and Tak 2009). Many songgye operated in the Geumsan region for hundreds of years and played key roles for the sustainable management of forest commons, until they became functionally obsolete in the mid-20th century (Kang 2001). Until the advent of fossil fuels and commercial fertilizers, the lives of most commoners heavily depended on sourcing these forest resources (Kang 2001, Chun and Tak 2009).

The main role of a songgye as a resource management organization was to provide three important types of public infrastructure. First, songgye provided institutions in the form of appropriation rules. For example, cutting down trees for firewood was usually prohibited, and members could only collect brushwood or dead trees during specified time periods a few times a year (Park 2000, Chun and Tak 2009). Second, songgye enabled communities to tackle challenges of infrastructure provision. Through songgye, a village as a whole could pool money to purchase a mountainous forest as common property (Kang 2001). Villagers also cooperated through songgye to repair mountain trails, essential infrastructure for enabling the mobility of resource appropriators (Kang 2001). Third, songgye facilitated monitoring of rule compliance and sanctioning of unauthorized activities. Some songgye had dedicated guards, while others had staff or ordinary members playing dual roles for guarding against intruders or rule-breakers (Kang 2001, Chun 2003).

\section{The drivers and consequences of change}

With the onset of industrialization in South Korea from the 1960s and 1970s, dramatic changes in context were imposed on the songgye of Geumsan. The nation's total demand for forest resources underwent a transition, starting from this period. Prior to industrialization, most South Koreans lived in rural areas and depended heavily on forest resources for home energy. For example, roughly $73 \%$ of the nation's annual primary energy consumption came from firewood during 1955 to 1960 (Fig. 2a; KCC 2001) and rural populations made up approximately $58 \%$ (14.6 million) of the 25 million people in 1960 (Bae and Lee 2006). However, in the 1960s and 1970s, the use of coal briquettes began to spread widely across the country for residential uses, even in rural areas, and substitute for firewood, and the use of foreign imported oil skyrocketed from the 1970s on (KESIS 2013). The use of firewood dropped dramatically (Fig. 2a) and by 1981 to 1990 , only $3 \%$ of the annual primary energy consumption came from firewood. South Korea also underwent a massive rural-tourban migration from the late 1960s on, driven by the search for better economic opportunities in urban areas (Figs. $2 \mathrm{~b}$ and $2 \mathrm{c}$ ). By 1992, rural population had declined to approximately 13\% (5.7 million) of the total population (43.7 million, BOK 2013). Driven in part by these trends, South Korea witnessed a striking turnaround in the nation's overall forest cover, from net deforestation to net reforestation (Fig. 2b). The nation's average use of commercial fertilizers also increased substantially during this period, from $162 \mathrm{~kg} / \mathrm{ha}$ in 1970 to $458 \mathrm{~kg} / \mathrm{ha}$ in 1990 (MAF 2005).

The use of coal briquettes and commercial fertilizers gained wide adoption in the 1960s and 1970s, and some of the more remote villages were deserted by the 1990s, which also affected Geumsan (Kang 2001). The overall forest cover of the area also increased tremendously, jumping by a factor of 13.4 between 1976 and 2010 (Table A.1 in Appendix 1). These drastic changes in context most likely rendered the songgye in Geumsan obsolete from the early 
Fig. 2. Changes in the broader context. A) Trends in average primary energy consumption and volume of growing stock from 1955 to 2003 (Source: KCC 2001, KESIS 2013). Other energy sources include coal, oil, gas, nuclear power, and hydro-power (TOE: tons of oil equivalent). B) Trends in rural population and volume of growing stock from 1934 to 2009 (Source: Bae and Lee 2006, BOK 2013, KFS 2010). The lines between the markers are linear interpolations. Note that the data before 1952 concerns the entire Korean Peninsula. C) Trends in earned income of urban household and farming income of rural household from 1970 to 2004 (Source: MAF 2005).

a.

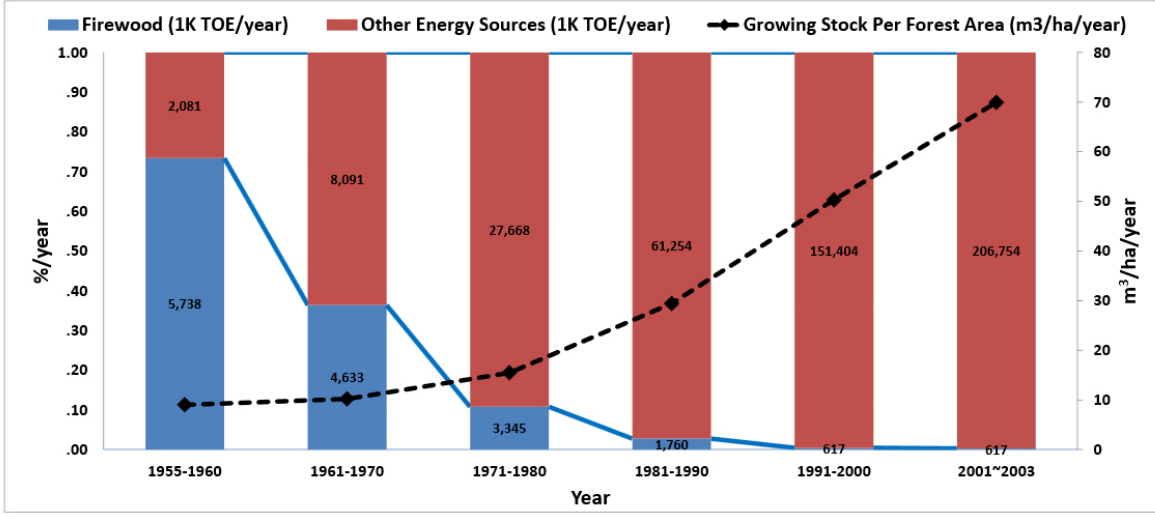

b.

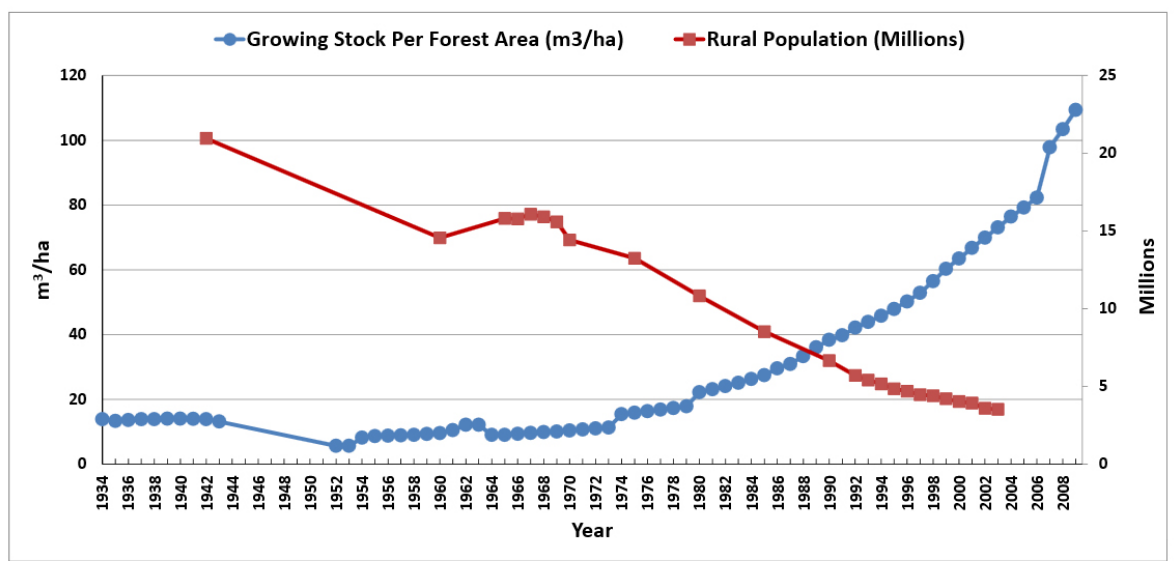

C.

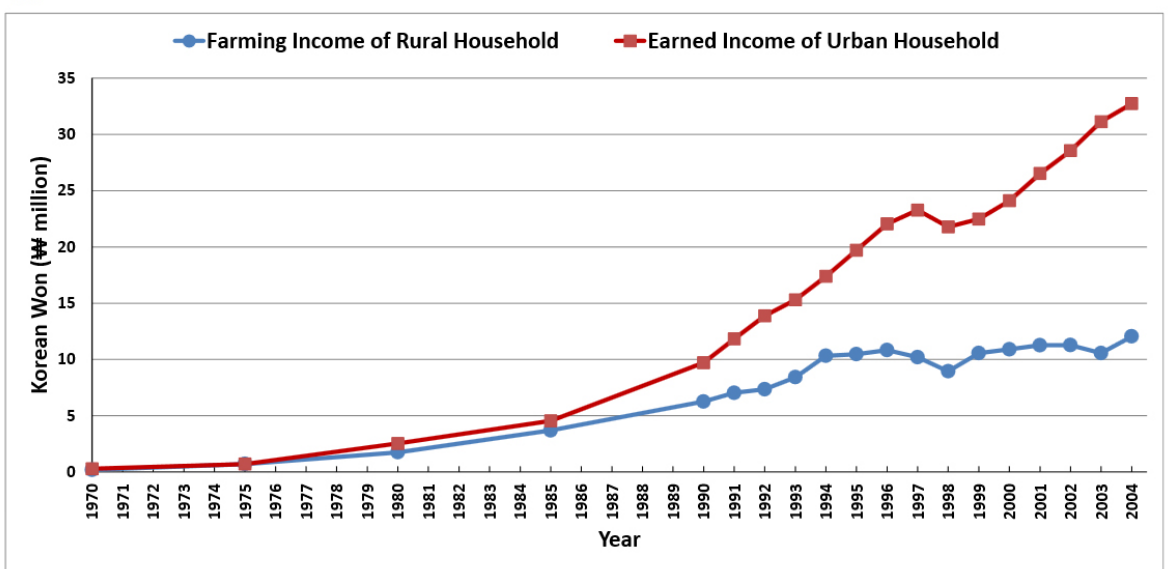


1960s, because of the tempered economic salience of the key forest resources that songgye were designed to govern (Kang 2001). In fact, no sightings of active songgye operations have been reported in the region since the 1960s (Kang 2001). After their collapse, the songgye in the region reorganized themselves in a number of different ways. The nature of their reorganization is the focus of this paper.

At the same time, a number of shifting sociopolitical trends also affected the decisions of local villagers as they weighed different options for reorganizing their songgye (Kang 2001). Beginning in the 1960s, the Korean government introduced a series of regional and national forestation plans to revitalize forests that were denuded by the Korean War and past overharvesting (Chun and Tak 2009, Bae et al. 2012). Rural villages were encouraged to organize tree-planting initiatives and to curb timber logging or other types of harvesting activities, such as slash-and-burn farming. The government also rolled out concerted public campaigns to change the mental models of rural villagers. Slogans such as "Planting is loving the nation" (Lee and Lee 2005) and "Cutting trees is a menace and planting trees is an act of patriotism" (Bae et al. 2012) were directed at the general public.

In some cases, legal disputes arose over unclear property rights regarding songgye forests. These disputes originated from a colonial-period forest policy introduced to restructure the traditional forest ownership and tenure system during the Japanese occupation period (1910-1945). Under this policy, songgye mountains were denied registration as commons. As such, many songgye in Geumsan had to register their forests as private properties under the names of village leaders (Kang 2001). This made the forests privately owned de jure but de facto commons. Finally, a real-estate boom pervaded the region throughout the 1980s and 1990s (Kang 2001). As a side effect of economic development, the value of songgye forests as a realestate commodity increased significantly around this time, and the benefits that could be extracted from forestry became further obscured (Kang 2001). This shifting valuation most likely influenced the decisions of local villagers during the transformation of their songgye.

\section{Data sources}

We conducted secondary analysis of the existing data that had been collected for a previous research project on songgye (Kang 2001). Published and endorsed by the Geumsan Cultural Center, Kang (2001) is the only large-N qualitative study done to uncover historical evidence of songgye operation at the study site. FAO 2005 provides a similar historical case study about songgye in the Anmyoen-do region of South Korea. More important for our purposes, Kang's study records how some of these songgye have reorganized themselves in the last 50 years. The 156 cases that are described by Kang (2001) offer a rare opportunity to explore general questions regarding the transformative capacity of SESs subjected to relatively rapid change associated with globalization.

For the data collection, Kang (2001) primarily relied on oral histories, interviews with key informants, and archival research. The use of such qualitative methods of data collection are common in historical case studies of collective action related to natural resources (Poteete et al. 2010). Kang's (2001) interview data came from 391 elderly local villagers who were identified to have some knowledge on the past practices of songgye as well as of past village-level decisions related to the use of songgye forests. Of the 391 informants, 388 were men, most of whom were likely heads of their households. The average age of the informants was 73.9 years. The documentary evidence came from the archival materials that included contracts of property rights and transactions involving songgye forests, legal documents settling disputes, and writings of constitutions of songgye. Kang conducted the research over 10 years from the early 1990s to 2001, during which he visited the site 80 times for fieldwork. Most of the interviews (98\%) were conducted between 1998 and 2001.

For the secondary analysis, we subsampled 89 cases based on two conditions: time coincidence of transformation events with the onset of economic development (around 1960) and presence of key variables, e.g., outcome of transformation and size of resource system. The first condition ensured that we were investigating transformative capacity under the influence of globalization. We thus restricted our analysis to the events that occurred in the period between 1960 and 1999. In the sample, 85 out of the 89 transformations occurred between the 1960s and 1980s. Note that we did not further group these 89 cases, even though different drivers of change may have been more important in different times. Our aim was to understand transformative capacity in relation to the general resilience of SESs under the broader influence of globalization, not their specific resilience or robustness in regard to specific disturbances (Folke et al. 2010). A word of caution about sampling bias is in order here. Because of the sampling criteria above, we were actually sampling the cases of more persistent songgye rather than all representative ones. Hence, any causal claims made here should be interpreted in relative terms, in the se0nse of the bias created here.

\section{Method and scope of analysis}

Growing theoretical literature on collective action posits that a large number of contextual factors potentially affect the likelihood of individuals to solve collective action problems (Agrawal 2002, Poteete et al. 2010). To identify relevant contextual factors and to compare user interactions and outcomes across the sample, we employed the ontological framework of SESs (Ostrom 2007; Ostrom 2009). Using the framework, we identified relevant similarities and differences in contextual factors and type of transformation among the sampled cases. Then we searched for plausible models for the relationship between type of transformation and contextual factors. Our approach reflects the methodological challenge raised by Basurto and Ostrom (2009), who assert that scholars should look for similarities and differences from rich details across multiple cases and combine theories to generate new hypotheses.

In our analysis, we focused on the roles of system-level factors, such as network diversity and biophysical context, rather than on the details of community interactions that are often emphasized in small-N case studies. Our focus on system-level factors is motivated by recognizing that SESs are complex adaptive systems (Levin and Clark 2010) in which emergent, system-level properties interact with individual-level processes to generate system dynamics. Of course, attributes of the community such as age and gender structure, existence of a local leader, and discussion during village meetings may affect the level of participation in community forest management (Lise 2000, Maskey et al. 2006). Thus, attributes of individual agents interact with biophysical 
context and rules-in-use in complex ways to produce governance outcomes (Ostrom 2005). Our aim was to complement these earlier studies on attributes of the community and rules-in-use by exploring the effects of the system-level or structural factors on which these community details play out. Much work remains to be done to understand the effects of these system-level factors in the context of social-ecological transformation (Folke et al. 2010). We also note that the details of the influences on the villagers' decision making of gender and age structure and community interactions during village meetings were unavailable in Kang's (2001) data. We suffer from the general limitation of all SES research: very few, if any, case studies exist that incorporate variables relating to all the components of SESs articulated in the SES Framework (Ostrom 2009) or the Robustness Framework (Anderies et al. 2004). As a result, we must use the data we have to study particular subsets of relationships within those frameworks.

\section{PATTERNS OF TRANSFORMATION}

By the early 1960s, all songgye in Geumsan had become dysfunctional. In the ensuing postfailure reorganization phases, villagers interacted in the arena of village assembly meetings to decide the fate of their now-obsolete forests. The village assembly, an overarching village organization that oversaw all types of coordinated tasks in a single village, existed for every village in the region (Kang 2001). Depending on the number of participating villages in a songgye, either a single village or multiple villages interacted in the decision-making process. All member households of a village assembly could voice their opinions and, if voting was necessary for the decision making, could cast a vote. In general, two broad types of actions were possible: actions favoring short-term self-interest and actions maintaining cooperative management in alternative ways. A village consensus, meaning unanimous or almost unanimous agreement, or voting, some sort of majority rule, was generally used for decision making at the village level, and the decision reached was binding for all members. When multiple villages were involved, decisions were usually made through two stages: each village would first decide on its preference and then all involved villages would have to agree unanimously if their shared assets were to be liquidated for other purposes (Kang 2001).

In the data, we observed four patterns of transformations. In pattern A, villages chose to maintain cooperative governance regimes and conserved their forests intact. In such cases, resource systems that had provided direct-use values were essentially transformed into public goods with intrinsic values. In pattern B, villages sold some or all of their forest resource systems and used the revenue raised to establish alternative community infrastructures. Examples include building village roads and bridges, purchasing lands for communal farming, constructing schools and community centers, and establishing communal funds (Kang 2001). In essence, these villages maintained their cooperative governance regimes in novel ways by converting their natural capital into new types of infrastructure that better met the modern-day needs of their communities. Pattern $\mathrm{C}$ was characterized by the release of some or all of the relevant natural capital with nothing contributed back to collective welfare. Motivated by short-term self-interest, villages in these instances sold their natural capital and simply divided the proceeds from the sale among village households. In pattern $\mathrm{D}$, we observed instances of property rights disputes motivated by unclear land titles. Despite the possibility of settling the conflict and preserving their communal forests, villagers in these instances failed to generate enough collective action to initiate formal legal actions, namely, collecting fees for upfront legal charges. In such cases, resource systems fell into the hands of a few opportunistic stakeholders (Kang 2001).

For our purposes, we further compacted the four observed patterns into two broader patterns, based on the degree of persistence of cooperation: cooperative transformation and noncooperative transformation. In the cooperative transformations, the common-pool resources provided by the forest were transformed into public goods, and cooperative governance was maintained in alternative forms (patterns A and B). In the noncooperative transformations, all of the forest resources were transformed into private gains, and cooperative governance was discontinued (patterns $\mathrm{C}$ and $\mathrm{D}$ ). This binary categorization constitutes our dependent variable in the statistical analysis. Our goal was to test whether there is a significant relationship between these patterns of transformation and the structure of SESs.

\section{CONTEXT OF TRANSFORMATION}

Some contextual factors were judged to be important for affecting the patterns of transformation. These factors constitute the explanatory variables in our statistical analysis.

\section{Social connectedness}

A web of village-level social connectedness developed in Geumsan as many villages adopted multilevel structures for the implementation of their songgye governance regimes prior to the 20 th century. Built on horizontal and vertical social linkages, multilevel governance is defined as having multiple centers or authorities of management and arrangements in which collective action is organized in multiple layers of nested enterprises (Ostrom 1990, Cox et al. 2010).

In Geumsan, three historical strategies played key roles for the development of songgye-related social connectedness: multiplevillage cooperation, diversity and redundancy in cooperative networks, and vertical nesting within village assemblies. Multiplevillage cooperation occurred whenever two or more villages formed an allied songgye by copurchasing a resource system and performing joint appropriation and provision activities under the supervision of a loosely formed intervillage council (Kang 2001; see Figs. $3 \mathrm{~b}$ and $3 \mathrm{~d}$ ). This practice reflects the design principle of nested enterprises in governing the commons (Ostrom 1990). We speculated that the resulting economy of scale and modularity of social systems better facilitated the provision of threshold public goods such as purchasing a large-scale mountainous forest and repairing mountain trails. For example, for purchasing forests, multiple villages acted together to increase their total group size, and they delegated each village to pool financial contributions from its member households. In this way, these allied villages were able to increase the level of the public good provision while decreasing the size of individual contributions and coordination costs. For the same reason, member villages of an allied songgye usually divided and maintained different sections of a network of trails (Kang 2001). In the cases where multiple-village 
Fig. 3. Types of village-to-songgye social connectedness. The link between a village and a forest represents a share in the property right of the forest and a participation in joint appropriation and provision activities. Triangles represent the biophysical boundary of the forest which is determined naturally by the physical boundary of a mountain along a contiguous range of mountains. The dashed rectangles indicate the institutional boundary of the songgye.

\section{a. Single village without cross-institutional link.}

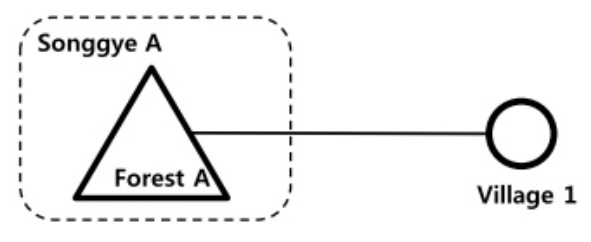

\section{c. Songgye A. single village with a cross- institutional link.}

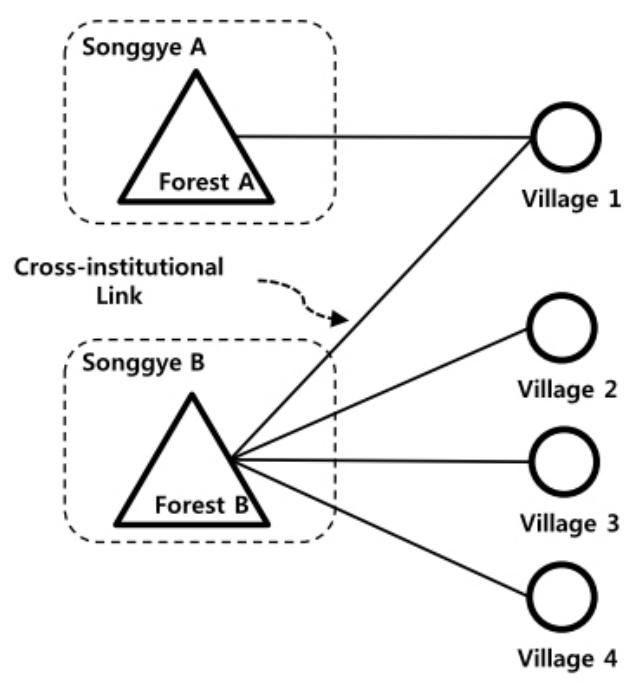

\section{b. Songgye A. multiple villages without cross-institutional links.}

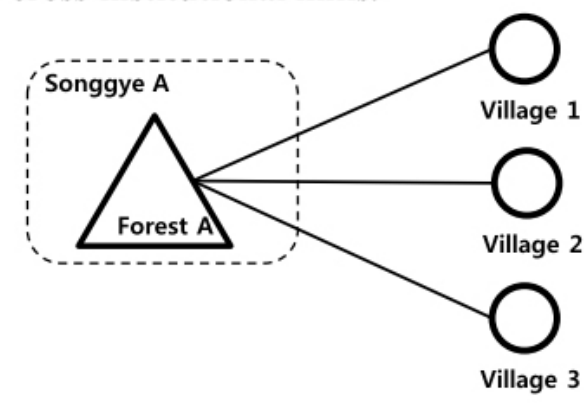

\section{d. Songgye A. multiple villages with cross-institutional links.}

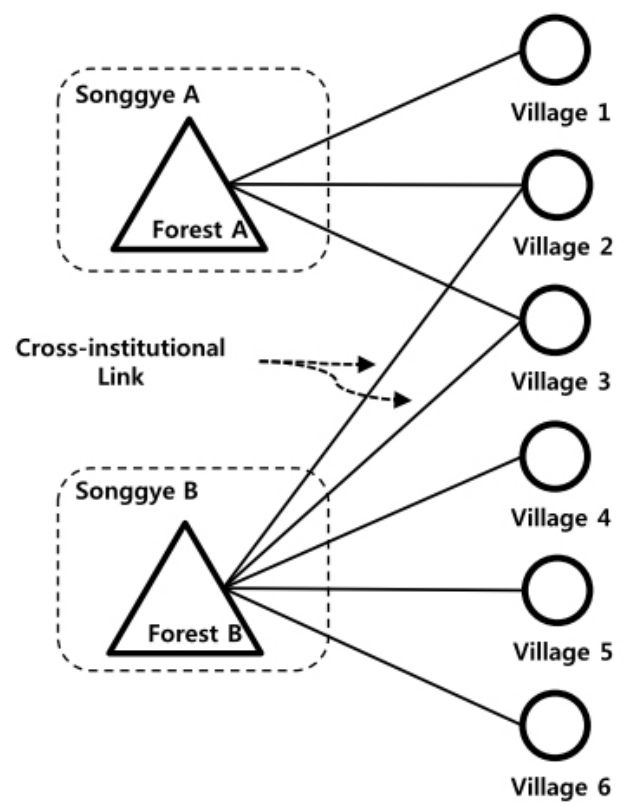

cooperation did not occur, a single village managed a mountainous forest by itself (see Figs. $3 a$ and 3c).

Diversity in cooperative networks arose whenever villages participated in multiple instances of songgye simultaneously, which resulted in the creation of cross-institutional links across different songgye (Figs. $3 \mathrm{c}$ and $3 \mathrm{~d}$ ). The resulting links of a village probably enabled that village to cope with varying biophysical conditions and uncertainties because of redundant flows of forest resources as well as to gain access to institutional diversity (for theoretical insights, see Elmqvist et al. 2003, Folke et al. 2005, Anderies and Janssen 2011). For example, some villages with existing songgye forests that were either unproductive or too distant from their village locations chose to join another songgye to access more productive or nearer forests (Kang 2001).

Vertical nesting occurred whenever songgye-related affairs in a single village were nested under that village's assembly (Fig. 4). Entire cases of songgye in Geumsan practiced vertical nesting (Kang 2001). We speculated that, through vertical nesting, a songgye could economize transaction costs by tapping into established leadership and legitimacy that already existed with village assembly. An additional layer of nesting occurred for allied songgye, because they were coordinated by intervillage councils (Fig. 4b) 
Fig. 4. Types of vertical linkages in songgye social structure.

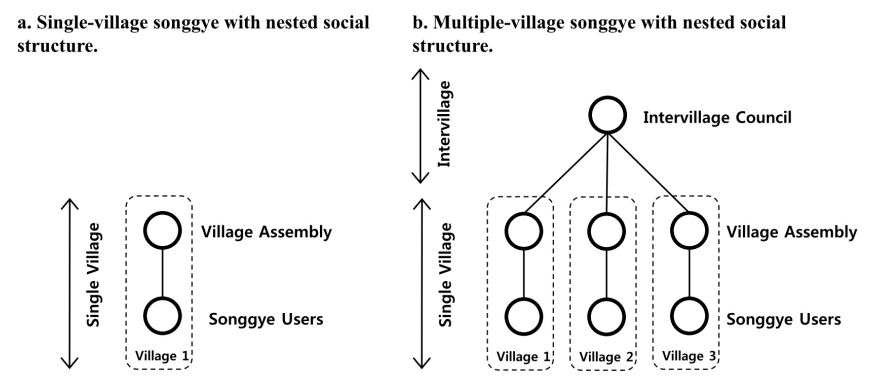

\section{Village location}

Depending on where villages are located, we speculated that the villages faced two biosocial heterogeneities in the past: variation in availability of forest resources in the villages' immediate surroundings and variation in degree of village-to-village social connectivity.

Most of the villages in the central districts (districts $\mathrm{E}$ and $\mathrm{H}$ in Fig. 1) are located in flat areas, and therefore lacked access to forests in their immediate surroundings. In the perimeter districts of B, C, F, I, and J, we observed multiple types of landscapes. Here, clusters of flat areas and mountainous terrains coexist in closer proximity. Kang (2001) suggests that the flat areas in the central and perimeter districts were the more populous areas, where villages tended to link seamlessly to one another without major spatial barriers. Most of the villages here probably had more neighboring villages and better intervillage social connectivity than those in more mountainous areas, but had less ease in finding harvestable forests nearby (Kang 2001). In contrast, most of the villages located in the mountainous areas (districts A, D, and G and parts of districts B, C, F, I, and J) tend to be isolated spatially by the natural barriers of mountain ranges. Intervillage social connectivity was probably lower there in the past as well, but these villages had better access to mountainous forests (Kang 2001).

\section{Resource systems and units}

Mountainous forests varied among songgye in terms of size and terrain characteristics. Some forests were large in area, encompassing as much as few hundred hectares. Some forests also differed in resource potential, having mostly rocky or gently sloping terrains. Regarding resource units, harvested items were mainly firewood and organic materials for composts. Some songgye, however, were different in that they historically exercised considerable dry-field farming inside their mountain regions as well and also allowed tenants to take over the farming in exchange for annual tenant fees (Kang 2001). In such cases, the collected fees became an important source of income for covering miscellaneous operating expenses of the songgye.

As for the forest conditions in terms of volume of growing stock and composition of tree species, there may have been some variation across songgye forests between 1960 and 1999. However, such data is unavailable for our study, and the decisions of villagers were probably negligibly affected by these conditions.
This is due to the fact, as can be deduced from Figure 2 and Table A.1, that the dominant trend was the declining user dependence on forest resources and the rise in forest cover, regardless of the decisions selected by songgye users.

\section{Summary: similarities and differences}

We outline here some key similarities and differences (explanatory variables) across the cases for the period between the 1960s and 1990s. The notable similarities are reduced economic salience of CPRs due to emergence of substitute goods, rapid economic development, exposure to a real-estate boom and reforestation policy by the government, unclear property rights, history of use, similar socioeconomic attributes of users, and decision-making through village assembly meetings. The key differences across the cases are outcome of transformation; number of villages, i.e., number of horizontally linked villages under a songgye; ratio of cross-institutional links; spatial extent of villages; topographic location of villages; size of resource system; terrain of resource system; and existence of tenant fees for dry-field farming.

Note that most of the similarities relate to the major drivers of change that were general and pervasive in nature. Because the songgye under study all derive from a single rural region that is monoethnic and monocultural in user characteristics, it is reasonable to assume that most of the songgye experienced the same level of shifting trends. Therefore, from a system-level perspective, notable differences across the cases mostly concerned the specifics of social connectedness and variations in villages' locations, topographic positions, resource systems, and units. Although the listed similarities and differences are not exhaustive, they largely cover the relevant information thought to be important for this research (see, e.g., Fleischman et al. 2010). Table 1 describes the variable definitions and measurements.

\section{DATA ANALYSIS}

To relate the likelihood of cooperative transformation to the contextual factors, we used multivariate logistic-regression models. We used a model-selection approach to hypothesis testing (Johnson and Omland 2004). We applied the Akaike Information Criterion (AIC) method (see Appendix 1 for details) to compare the fits of all possible combinations of explanatory variables (Burnham and Anderson 2002). AIC is calculated for a suite of models. The absolute size of the AIC is unimportant; instead the difference in AIC values between models indicates the relative support for the models. To compare models, we calculated Akaike weights (Burnham and Anderson 2002). We considered as plausible models those with Akaike weights that were within 10\% of the highest weight. We also reported the relative importance of the explanatory variables as the sum of Akaike weights over all models. The relative variable importance is the probability that, of the variables considered, a certain variable is in the bestapproximating model.

Finally, we studied correlations between topographic location of villages and their songgye-related social connectedness. If social connectedness is associated with topographic location and also with different trajectories of transformation, we could infer that optimizing for robustness (i.e., forming social connectedness) to past conditions (i.e., variations in resource flow stemming from topographic location) possibly affected the transformative capacity of songgye in the present day. 
Table 1. Variable descriptions.

\begin{tabular}{ll}
\hline \hline Variables & Definitions \\
\hline $\begin{array}{l}\text { Dependent variable: } \\
\text { Outcome of transformation }\end{array}$ & $\begin{array}{l}\text { The outcome of transformation is categorized into two broad types: (1) cooperative transformation and } \\
\text { (2) noncooperative transformation }(=1 \text { if cooperative; }=0 \text { if noncooperative }) .\end{array}$
\end{tabular}

Independent variables: Number of villages

A number of villages in a songgye that are horizontally linked through shared property rights of a resource system and joint appropriation and provision activities. For songgye A in Fig. 3a and c, this measure is 1. In Fig. $3 b$ and d, this measure is 3 .

Ratio of cross-institutional links The ratio of cross-institutional links measures the percentage of participating villages in a songgye that participate in multiple instances of songgye simultaneously. ${ }^{\dagger}$ For songgye A in Fig. 3a and b, this measure is 0 . In Fig. 3c, this is $100 \%$. In Fig. 3d, this is $2 / 3$ or $67 \%$.

Spatial extent of villages The spatial extent is measured by the scale of administrative districts spanned by participating villages (= 0 if one village is involved; $=1$ if multiple villages are involved, but all are situated within one subdistrict; and $=2$ if multiple villages are involved and are situated over multiple subdistricts).

Topographic location of villages The percentages of flat areas in the surrounding areas of participating villages are averaged to derive this measure. $^{\ddagger}$

Size of resource system

The size of resource system measures the physical area covered by a songgye's mountainous forests ( $=0$ if $1-10$ hectares; $=1$ if $11-100$ hectares; and = 2 if greater than 100 hectares). ${ }^{\S}$

Terrain of resource system

The terrain type is estimated from the existence of considerable dry-field farming inside songgye mountains $(=1$ if considerable dry-field farming exists, i.e., presence of large mildly sloping terrain; $=0$ otherwise)

Existence of tenant fees

The functional diversity carried by the resource system is measured by the existence of annual tenant fees levied for the rights to exercise dry-field farming inside songgye mountains. It gauges whether or not the villages were able to extract extra benefits from their mountains (= 1 if annual tenant fees were collected; $=0$ otherwise).

\footnotetext{
$\dagger$ Because these links in a given songgye can adjust over time as associated songgye undergo transformations, we take a snapshot of these links (taken at 1960) as our basis of analysis.

\$ The topographic position index (TPI; Weiss 2001) was derived for each subdistrict that contains member villages. For each subdistrict, flat areas and lower slopes are divided by the total subdistrict area. This percentage was then averaged over all involved subdistricts.

$\S$ The physical size is ordinal because some of the empirical cases provided estimated ranges of area instead of exact figures.
}

\section{RESULTS}

\section{Descriptive statistics}

The majority $(73 \%)$ of the transformations were cooperative: 36 cases $(40 \%)$ of pattern A, conservation of community forests, and 29 cases $(33 \%)$ of pattern B, conversion to alternative community infrastructures. The remaining transformations were noncooperative: 19 cases $(21 \%)$ of pattern C, selling out, and 5 cases $(6 \%)$ of pattern $\mathrm{D}$, legal disputes over property rights. The notable trends in descriptive statistics were the contrasts in the averages of the number of villages involved and ratios of cross-institutional links (Tables 2 and 3). The average of the number of villages involved in the cooperative transformations was lower (2.2) than its counterpart (6.3) in noncooperative transformations (Table 3). The average of cross-institutional links among the cooperative cases was higher (0.6) than it was among the noncooperative cases (0.3).

\section{Model selection}

Model selection results suggested that 20 models could be considered as plausible (Table 4). Given the data and set of candidate models, the best explanatory model is the one that included "number of villages" and "ratio of cross-institutional links." "Number of villages" was included in all of the plausible models with a negative response. "Number of villages" had a probability of 0.87 of being in the best-approximating model with a positive response. Thus, cooperative outcomes were associated with lower number of villages and a higher proportion of cross- linked villages. "Existence of tenant fees" had a probability close to 0.5 of being in the best model, and with the previous two variables formed the second plausible model. The association of outcomes with "existence of tenant fees" was negative. The third model added "terrain of resource systems" to the best model. This variable had a probability of 0.31 with a negative coefficient. The fourth model added "topographic location of villages" to the best model. This variable had a probability of 0.32 of being in the bestfitting model, and its response was negative. "Size of resource system" was added in the fifth plausible model. This variable had a probability of 0.31 with a positive coefficient. Finally, the "spatial extent of villages" first appears in the seventeenth plausible model. This variable had a low probability $(0.14)$ of being in the best-fitting model with a positive coefficient.

Association between social connectedness and biophysical context We ran correlation analyses to test whether the biophysical context (topographic location) of a village was associated with its social connectedness. We first tested the association between the topographic location of a village and the group size of each songgye, the number of villages that the village belonged to. A topographic position index, or TPI (Weiss 2001), was derived for each subdistrict that contained member villages. For each subdistrict, areas of flat and lower slopes were divided by the total subdistrict area to derive the percentage of flat terrains. For the group size, our unit of analysis was associations between a village and its participations in one or more songgye. Because we are dealing with past robustness, we applied all 156 cases of songgye 
Table 2. Categorical variable statistics by cooperative and noncooperative transformations. For details, see Table 1.

\begin{tabular}{|c|c|c|c|c|c|c|}
\hline \multirow[t]{2}{*}{ Variables } & \multicolumn{3}{|c|}{$\begin{array}{l}\text { Noncooperative transformation } \\
(\mathrm{N}=24) \\
\text { Frequency }(\%) \\
\end{array}$} & \multicolumn{3}{|c|}{$\begin{array}{l}\text { Cooperative transformation } \\
(\mathrm{N}=65) \\
\text { Frequency }(\%) \\
\end{array}$} \\
\hline & $(=0)$ & $(=1)$ & $(=2)$ & $(=0)$ & $(=1)$ & $(=2)$ \\
\hline Size of resource system & $5(21 \%)$ & $13(54 \%)$ & $6(25 \%)$ & $19(29 \%)$ & $36(55 \%)$ & $10(15 \%)$ \\
\hline Terrain of resource system & $13(54 \%)$ & $11(46 \%)$ & & $44(68 \%)$ & $21(32 \%)$ & \\
\hline Existence of tenant fees & $6(25 \%)$ & $18(75 \%)$ & & $25(38 \%)$ & $40(62 \%)$ & \\
\hline Spatial extent of villages & $11(46 \%)$ & $5(21 \%)$ & $8(33 \%)$ & $42(65 \%)$ & $10(15 \%)$ & $13(13 \%)$ \\
\hline
\end{tabular}

Table 3. Continuous variable statistics by cooperative and noncooperative transformations. For details, see Table 1.

\begin{tabular}{lcccccccc}
\hline Variables & \multicolumn{3}{c}{ Noncooperative transformation } & & \multicolumn{3}{c}{ Cooperative transformation } \\
\cline { 2 - 4 } \cline { 7 - 8 } & Mean & Std. Dev. & Min, Max & & Mean & Std. Dev. & Min, Max \\
\cline { 2 - 4 } Number of member villages & 6.330 & 9.020 & 0.39 & & 2.185 & 2.567 & 1.16 \\
Ratio of cross-institutional links & 0.344 & 0.423 & 0.1 & & 0.561 & 0.486 & 0.1 \\
Topographic location of villages & 0.244 & 0.127 & $0.051,0.558$ & & 0.221 & 0.119 & $0.051,0.610$ \\
\hline
\end{tabular}

Table 4. Plausible models identified by the AIC method. For each model, the table indicates the coefficient of the variables included, the number of parameters (df), log-likelihood (logLik), delta weight ( $\triangle \mathrm{AIC}$, difference between the AIC for a given model and the AIC of the best-fitting model), and Akaike weights ( $w$, the model selection probability). Averaged coefficients and the relative variable importance are also presented. The Akaike weight is the probability that a model would be selected as the best-fitting model if the data were collected again under identical circumstances. Model averaged estimates are weighted by their Akaike weight.

\begin{tabular}{|c|c|c|c|c|c|c|c|c|c|c|c|c|}
\hline Model & df & (Intercept) & $\begin{array}{l}\text { Spatial } \\
\text { extent } \\
\text { of } \\
\text { villages }\end{array}$ & $\begin{array}{l}\text { Existence of } \\
\text { tenant fees }\end{array}$ & $\begin{array}{l}\text { Topographic } \\
\text { location of } \\
\text { villages }\end{array}$ & $\begin{array}{l}\text { Number of } \\
\text { member } \\
\text { villages }\end{array}$ & $\begin{array}{c}\text { Ratio of } \\
\text { cross- } \\
\text { institutional } \\
\text { links }\end{array}$ & $\begin{array}{l}\text { Terrain of } \\
\text { resource } \\
\text { systems }\end{array}$ & $\begin{array}{l}\text { Size of } \\
\text { resource } \\
\text { system }\end{array}$ & $\log \mathrm{Lik}$ & $\Delta \mathrm{AIC}$ & $w$ \\
\hline 1 & 3 & 1.1059 & - & - & - & -1.0601 & 0.6322 & - & - & -44.09 & 94.19 & 0.12 \\
\hline 2 & 4 & 1.1254 & - & - & - & -1.1117 & 0.6114 & - & - & -43.24 & 94.47 & 0.10 \\
\hline 3 & 4 & 1.1091 & - & -0.3664 & - & -1.0242 & 0.6667 & -0.2176 & - & -43.78 & 95.55 & 0.06 \\
\hline 4 & 4 & 1.1163 & - & - & -0.2259 & -0.9973 & 0.7214 & - & - & -43.85 & 95.70 & 0.06 \\
\hline 5 & 6 & 0.9612 & - & -0.4227 & - & -1.5737 & 0.6889 & - & -0.0923 & -41.88 & 95.75 & 0.05 \\
\hline 6 & 5 & 1.1409 & - & -0.3863 & -0.2598 & -1.0257 & 0.7069 & - & - & -42.91 & 95.82 & 0.05 \\
\hline 7 & 5 & 0.8885 & - & - & - & -1.4457 & 0.7125 & - & 0.0064 & -42.93 & 95.85 & 0.05 \\
\hline 8 & 5 & 1.1254 & - & -0.3348 & - & -1.0959 & 0.6264 & -0.0710 & - & -43.21 & 96.42 & 0.04 \\
\hline 9 & 6 & 0.8829 & - & - & - & -1.4584 & 0.7606 & -0.2790 & -0.0081 & -42.43 & 96.86 & 0.03 \\
\hline 10 & 5 & 1.1238 & - & - & -0.2585 & -0.9443 & 0.7760 & -0.2464 & - & -43.46 & 96.91 & 0.03 \\
\hline 11 & 7 & 0.9199 & - & -0.4429 & -0.2941 & -1.5067 & 0.8027 & - & -0.0218 & -41.48 & 96.96 & 0.03 \\
\hline 12 & 6 & 0.8402 & - & - & -0.2638 & -1.3957 & 0.8240 & - & 0.08224 & -42.61 & 97.22 & 0.03 \\
\hline 13 & 3 & 1.0528 & - & -0.4015 & - & -0.9802 & - & - & - & -45.70 & 97.40 & 0.02 \\
\hline 14 & 2 & 1.0207 & - & - & - & -0.9109 & - & - & - & -46.78 & 97.56 & 0.02 \\
\hline 15 & 7 & 0.9530 & - & -0.3676 & - & -1.5649 & 0.7160 & -0.1257 & -0.0908 & -41.79 & 97.59 & 0.02 \\
\hline 16 & 6 & 1.1420 & - & -0.3444 & -0.2674 & -1.0029 & 0.7315 & -0.0942 & - & -42.87 & 97.73 & 0.02 \\
\hline 17 & 5 & 0.9564 & 1.0000 & - & - & -1.2842 & 0.5691 & - & - & -43.92 & 97.83 & 0.02 \\
\hline 18 & 7 & 0.8127 & - & - & -0.3069 & -1.4014 & 0.9021 & -0.3128 & 0.1034 & -42.00 & 98.00 & 0.02 \\
\hline 19 & 6 & 0.9913 & 1.0000 & -0.3573 & - & -1.3017 & 0.5583 & - & - & -43.11 & 98.22 & 0.02 \\
\hline 20 & 8 & 0.8989 & - & -0.3745 & -0.3068 & -1.4952 & 0.8450 & -0.1518 & -0.0017 & -41.36 & 98.73 & 0.01 \\
\hline \multicolumn{2}{|c|}{ Averaged coefficients } & 1.0230 & 0.0046 & -0.1788 & -0.0802 & -1.2054 & 0.6007 & -0.0536 & -0.0110 & & & \\
\hline \multicolumn{2}{|c|}{ Relative variable importance } & 1.00 & 0.14 & 0.46 & 0.32 & 1.00 & 0.87 & 0.31 & 0.31 & & & \\
\hline
\end{tabular}


as the sample. Because some villages joined more than one songgye, the total count of associations was 501, although the total number of villages was 338 . The association was significant $(p<0.001)$ with a modest correlation (Pearson's $r=0.365)$. This suggests that villages situated in a flat valley were more likely to be a member of an allied songgye than villages located in mountainous areas. This make intuitive sense: with more neighbors and less resource availability in its immediate surroundings, a village located in a valley probably had more incentives to cooperate with others to economize costs of operating a songgye. The association between the topographic location and whether a village carried at least one crossinstitutional link is not significant $(p>0.05)$.

\section{DISCUSSION}

Our research began with the assertion that, given the process of globalization now underway, the study of the commons needs to not only address whether cooperation arises or fails in a given set of biophysical, social, and economic circumstances, but also to begin to understand the dynamics of cooperation as those circumstances change. Here we focus on some dimensions of postfailure processes and the question of what factors help explain the nature of the postfailure transformation of selfgoverned CPR systems. In the current body of literature, we found no studies that directly attempted to answer this question in a structured way. Most of the studies either focused on relationships among aspects of specific disturbances, responses, and vulnerability trade-offs or depended on either a single case or a small-N set of cases, which could not offer understanding of the underlying structure for observed patterns of transformation in a statistically significant way.

From analyzing 89 songgye in Geumsan that underwent transformations under globalization, we found that the transformations were either cooperative or noncooperative. The majority of the observed transformations were cooperative (65 out of 89). The presence of these two broader trajectories of transformation simply reflects the nature of a dilemma faced by the users: whether to continue to pursue some social welfare, as they had previously, or to opt for private gains. The fact that the majority of the observed transformations were cooperative may be explained by the sampling bias we introduced by selecting only those songgye that remained intact until the early 1960s, which implies that our sample probably consisted of villages that were inherently high in social capital. Such higher levels of social capital probably enabled many villages to pursue some form of collective welfare in spite of the apparent temptation to pursue individual gains during transformations.

The best-fitting model shows that cooperative transformations are negatively correlated with the number of villages in a songgye. On the other hand, cooperative transformations are positively associated with the ratio of cross-institutional links. The opposite is true for noncooperative transformations. The direction of association exhibited by the number of villages in a songgye is consistent with the transaction cost hypothesis of group size: the more participants there are in a collective action problem, the more difficult it is to organize collective action, because of higher coordination or transaction costs (Poteete and Ostrom 2004, Araral 2009). Because participant villages in a songgye act cohesively as single actors at the system level, the number of member villages is a scale-invariant representation of group size.
As such, songgye with higher counts of member villages probably faced greater transaction costs and thus were less likely to maintain collective action through transformations. This speculation is consistent with the observed patterns in our sample data. One might ask then why such songgye with large group sizes even existed in the first place. In the past, their emergence was probably possible or was even welcomed, because the salience of forest resources for villager livelihoods was high and the necessary public infrastructure, e.g., mountain trails, were threshold public goods that required economy of scale in contributions of human effort.

What we find more interesting is the positive association between the ratio of cross-institutional links and the prospect of villages engaging in more cooperative transformations. Such links emerged when the villages in Geumsan participate in multiple instances of songgye simultaneously. We speculate that these villages with cross-institutional links may have functioned as bridging actors or connectors who facilitated information exchanges and brought in networks of contacts that helped local communities to gain access to new ideas and resources as well as institutional diversity (Westley 1995, Folke et al. 2005). In the past, these villages probably fostered circulation of more diverse and up-to-date knowledge, useful for governing forest commons sustainably. Similarly, in the modern-day situations of transformation driven by globalization, the presence of such connectors probably mitigated the problem of information uncertainties regarding available trajectories of transformation and the associated costs and benefits. For example, the presence of bridging villages may have better facilitated circulation of information regarding the serviceability of new community infrastructure that villagers were not aware of, what the social value of a conservation infrastructure or alternative public infrastructure could be, or what the expected market value of a forest might have been if sold.

We found some evidence that there was a potential trade-off between robustness and transformative capacity of songgye. Our analysis showed that the topographic location of a village and the number of its horizontal links are significantly associated. Given that this connectedness resembles multilevel governance structures, which are known to enhance adaptive capacity and thus robustness of social systems (Ostrom 1996, Folke et al. 2005, Marshall 2008), we could infer the following: such connectedness evolved in Geumsan in part because of the villages' efforts to ensure a robust supply of key resources, firewood and organic materials for composts, despite variations in biophysical conditions. In the past, the emergence of such context-dependent connectedness probably gave those songgye more robustness to the uncertainty of resource flows. For example, from the horizontal links, such songgye probably had more local adaptability and economy of scale for providing collective goods. However, when pressures associated with globalization finally necessitated transformations, the advantages of horizontal links no longer applied and the transaction costs associated with horizontal links may have dominated the transformation action situation.

Finally, we reflect on the effects of the remaining independent variables. Although these variables were absent in the best-fitting model, we can make the following assessments. The negative associations of the cooperative outcomes with "existence of 
tenant fees," "terrain of resource system," and "topographic location of villages" may imply that when these variables have larger values, the forests probably have more favorable terrains and locations and thus more potential for alternative uses. This could mean higher opportunity costs for transforming cooperatively. Contrary to our expectation, "existence of tenant fees" is negatively associated with cooperative outcomes. A possible explanation is that slash-and-burn farming was strongly curbed by the national-level forestation policies from the early 1970s, meaning no more revenue from tenants (Bae and Lee 2006). The positive associations of cooperative outcomes with "size of resource system" and "spatial extent of villages" may be explained by the observation that some songgye with large-scale resource systems that were spread over multiple subdistricts chose to informally subdivide their forests among their member villages (Kang 2001). This informal subdivision of shared property rights could have given those member villages more incentives for transforming cooperatively.

\section{CONCLUSION}

From the above analysis, we may draw some conclusions about the transformative capacity of SESs subjected to the growing extent and intensity of global interconnectedness. When selfgoverned common-pool resource systems become untenable as a result of globalization, those systems with lower transaction costs, i.e., smaller group size, and higher network diversity, i.e., more ties to others through linkages such as cross-linked property rights or shared institutional memory, are more likely to organize transformations that still preserve some form of collective welfare. Conversely, previously highly efficient systems that relied on economy of scale and undivided participation from multiple social systems through nested enterprise may become more vulnerable to transforming uncooperatively when they become untenable. The present paper is limited in scope. Further studies in other contexts may find different empirical patterns and different variables to be more important. The accumulation of different insights from different contexts and their comparisons, including ours, will only lead to a fuller understanding of the transformative capacity of SESs.

Responses to this article can be read online at: http://www.ecologyandsociety.org/issues/responses. $\mathrm{php} / 6135$

\section{Acknowledgments:}

Dowon Lee contributed to this article, and was supported by a National Research Foundation of Korea (NRF) grant funded by the Korean Ministry of Education, Science and Technology (MEST), grant No. 2010-0009912. Hyunwoo Lee and the Korea Environment Institute also contributed to this work financially, by supporting our data collection efforts in South Korea. David Yu and John Anderies gratefully acknowledge financial support from the National Science Foundation, Grant numbers SES-0645789 and GEO-1115054. Irene Pérez was partially supported by Fundación SéNeCa (Murcia, Spain) under a postdoctoral fellowship. Wanmo Kang and Kwanghoon Choi aided the research by producing the map of Geumsan and extracting the topographic position index of
Geumsan. Last but not least, we thank Sungbok Kang for his amazing field study of the songgye in Geumsan. Without his descriptions of the 156 songgye, this research could not have been done. At present, this work exists only in the Korean language. It can be obtained at no charge from the Geumsan Cultural Center: http://geumsan.cult21.or. $\mathrm{kr}$

\section{LITERATURE CITED}

Abel, N., D. H. M. Cumming, and J. M. Anderies. 2006. Collapse and reorganization in social-ecological systems: questions, some ideas, and policy implications. Ecology and Society 11(1): 17. [online] URL:_http://www.ecologyandsociety.org/vol11/iss1/ $\underline{\operatorname{art} 171}$

Agrawal, A. 2002. Common resources and institutional sustainability. Pages 41-85 in E. Ostrom, T. Dietz, N. Dolšak, P. C. Stern, S. Stonich, and E. U. Weber, editors. The drama of the commons. National Academy Press, Washington, D.C., USA. http://www.nap.edu/openbook.php?record id=10287\&page $=41$

Anderies, J. M. 2006. Robustness, institutions, and large-scale change in social-ecological systems: the Hohokam of the Phoenix Basin. Journal of Institutional Economics 2:133. http://dx.doi. org/10.1017/S1744137406000312

Anderies, J. M., and M. A. Janssen. 2011. The fragility of robust social-ecological systems. Global Environmental Change 21:1153-1156. http://dx.doi.org/10.1016/j.gloenvcha.2011.07.004

Anderies, J. M., M. A. Janssen, and E. Ostrom. 2004. A framework to analyze the robustness of social-ecological systems from an institutional perspective. Ecology and Society 9(1): 18. [online] URL: http://www.ecologyandsociety.org/vol9/iss1/art18/

Araral, E. 2009. What explains collective action in the commons? Theory and evidence from the Philippines. World Development 37:687-697. http://dx.doi.org/10.1016/j.worlddev.2008.08.002

Bae, J. S., R. W. Joo, and Y.-S. Kim. 2012. Forest transition in South Korea: reality, path and drivers. Land Use Policy 29:198-207. http://dx.doi.org/10.1016/j.landusepol.2011.06.007

Bae, J. S., and K. B. Lee. 2006. Drivers of forest recovery in South Korea: substitution of residential energy sources and large-scale afforestation. [Title translated from the Korean] Korea Forest Research Institute, Seoul, Korea.

Bank of Korea (BOK). 2013. Bank of Korea Economic Statistics System. Bank of Korea. [online] URL: http://ecos.bok.or.kr/ EIndex en.jsp"

Bartón, K. 2012. Package 'MuMIn': Multi-model inference. R package version 1.7.9. R Foundation for Statistical Computing, Vienna, Austria. [online] URL: http://cran.r-project.org/web/ packages/MuMIn/MuMIn.pdf

Basurto, X., and E. Ostrom. 2009. The core challenges of moving beyond Garrett Hardin. Journal of Natural Resources Policy Research 1:255-259. http://dx.doi.org/10.1080/19390450903040447

Biggs, R., F. R. Westley, and S. R. Carpenter. 2010. Navigating the back loop: fostering social innovation and transformation in ecosystem management. Ecology and Society 15(2): 9. [online] URL: http://www.ecologyandsociety.org/vol15/iss2/art9/ 
Burnham, K. P., and D. R. Anderson. 2002. Model selection and multimodel inference: a practical information-theoretic approach. Springer, New York, New York, USA.

Chun, Y. 2003. Songgye (pine guild) from a forestry point of view. [Title translated from the Korean] Forest and Humanity 15:5-20.

Chun, Y. W., and K.-I. Tak. 2009. Songgye, a traditional knowledge system for sustainable forest management in Choson Dynasty of Korea. Forest Ecology and Management 257:2022-2026. http://dx.doi.org/10.1016/j.foreco.2008.11.038

Cox, M., G. Arnold, and S. Villamayor Tomás. 2010. A review of design principles for community-based natural resource management. Ecology and Society 15(4): 38. [online] URL: http:// www.ecologyandsociety.org/vol15/iss4/art38/

Elmqvist, T., C. Folke, M. Nyström, G. Peterson, J. Bengtsson, B. Walker, and J. Norberg. 2003. Response diversity, ecosystem change, and resilience. Frontiers in Ecology and the Environment 1(9):488-494. http://dx.doi.org/10.1890/1540-9295(2003)001[0488: RDECAR]2.0.CO;2

Fleischman, F. D., K. Boenning, G. A. Garcia-Lopez, S. Mincey, M. Schmitt-Harsh, K. Daedlow, M. Lopez, X. Basurto, B. Fischer, and E. Ostrom. 2010. Disturbance, response, and persistence in self-organized forested communities: analysis of robustness and resilience in five communities in Southern Indiana. Ecology and Society 15(4): 9. [online] URL: http://www. ecologyandsociety.org/vol15/iss4/art9/

Folke, C., S. R. Carpenter, B. Walker, M. Scheffer, T. Chapin, and J. Rockström. 2010. Resilience thinking: integrating resilience, adaptability and transformability. Ecology and Society 15(4): 20. [online] URL: http://www.ecologyandsociety.org/vol15/iss4/ $\underline{\operatorname{art} 20 /}$

Folke, C., T. Hahn, P. Olsson, and J. Norberg. 2005. Adaptive governance of social-ecological systems. Annual Review of Environment and Resources 30:441-473. http://dx.doi.org/10.1146/ annurev.energy.30.050504.144511

Food and Agriculture Organization of the United Nations (FAO). 2005. In search of excellence: exemplary forest management in Asia and the Pacific. P. B. Durst, C. Brown, H. D. Tacio, and M. Ishikawa, editors. International Forestry Review. Asia-Pacific Forestry Commission, Food and Agriculture Organization, Bangkok, Thailand. [online] URL: http://www.un.or.id/ documents upload/publication $/ \operatorname{In} \% 20$ search $\% 20$ of $\% 20$ excellence $\%$ 20\%20 exemplary $\% 20$ forest $\% 20$ management $\% 20 \mathrm{in} \% 20$ Asia $\% 20$ and $\%$ 20the $\% 20$ Pacific.pdf

Gelcich, S., T. P. Hughes, P. Olsson, C. Folke, O. Defeo, M. Fernández, S. Foale, L. H. Gunderson, C. Rodríguez-Sickert, M. Scheffer, R. S. Steneck, and J. C. Castilla. 2010. Navigating transformations in governance of Chilean marine coastal resources. Proceedings of the National Academy of Sciences of the United States of America 107(39):16794-16799. http://dx.doi. org/10.1073/pnas.1012021107

Janssen, M. A., J. M. Anderies, and E. Ostrom. 2007. Robustness of social-ecological systems to spatial and temporal variability. Society \& Natural Resources 20:307-322. http://dx.doi. org/10.1080/08941920601161320
Johnson, J. B., and K. S. Omland. 2004. Model selection in ecology and evolution. Trends in Ecology and Evolution 19(2):101-108. http://dx.doi.org/10.1016/j.tree.2003.10.013

Kang, S. 2001. The songgye of Geumsan. [Title translated from the Korean] Geumsan Cultural Center, Geumsan, Korea.

Korea Coal Corporation (KCC). 2001. The 50-year history of Korea Coal Corporation: 1950-2000. [Title translated from the Korean] Korea Coal Corporation, Seoul, Korea.

Korea Energy Statistics Information System (KESIS). 2013. Korea Energy Statistics Information System, Seoul, Korea. [Title translated from the Korean]

Korea Forest Service (KFS). 2010. Forest land area and growing stock by year. [Title translated from the Korean] Korea Forest Service, Daejon, Korea. [online] URL: http://www.forest.go.kr/ newkfsweb/cop/bbs/selectBoardArticle.do?nttId=61424\&bbsId= BBSMSTR 1016\&pageIndex $=1$ \&pageUnit $=10 \&$ searchtitle $=$

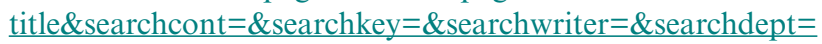
\&searchWrd=\&ctgryLrcls=CTGRY070\&ctgryMdcls=\&ctgrySmcls= $\underline{\text { \&ntcStartDt=\&ntcEndDt=\&org } I d=k f s \& m n=K F S 0407}$

Korea Forest Service (KFS). 2013. Basic statistics of regional forestry. [Title translated from the Korean] Korea Forest Service, Daejon, Korea. [online] URL: http://www.forest.go.kr/ newkfsweb/kfi/kfs/stats/localStats.do?mn=KFS 040101

Korean National Statistical Office (KNSO). 2013. Basic statistics of forestry. [Title translated from the Korean] Korean National Statistical Office, Seoul, Korea. [online] URL: http://kosis.kr/eng/ database/database_001000.jsp?listid $=$ Z

Lee, D. K. and Y. K. Lee. 2005. Roles of Saemaul Undong in reforestation and NGO activities for sustainable forest management in Korea. Journal of Sustainable Forestry 20:1-16. http://dx.doi.org/10.1300/J091v20n04 01

Levang, P., S. Sitorus, and E. Dounias. 2007. City life in the midst of the forest: a Punan hunter-gatherer's vision of conservation and development. Ecology and Society 12(1): 18. [online] URL: http://www.ecologyandsociety.org/vol12/iss1/art18/

Levin, S., and W. Clark. 2010. Toward a science of sustainability. Center for International Development Working Paper 196, John F. Kennedy School of Government, Harvard University, Cambridge, Massachusetts, USA. [online] URL: http://www.hks. harvard.edu/centers/cid/publications/faculty-working-papers/cidworking-paper-no.-196

Lise, W. 2000. Factors influencing people's participation in forest management in India. Ecological Economics 34 (3):379-392. http://dx.doi.org/10.1016/S0921-8009(00)00182-8

Marshall, G. R. 2008. Nesting, subsidiarity, and communitybased environmental governance beyond the local level. International Journal of the Commons 2(1):75-97.

Maskey, V., T. G. Gebremedhin, and T. J. Dalton. 2006. Social and cultural determinants of collective management of community forest in Nepal. Journal of Forest Economics 11 (4):261-274. http://dx.doi.org/10.1016/j.jfe.2005.10.004 
Ministry of Agriculture and Forestry (MAF). 2005. Major statistics of agriculture and forestry. [Title translated from the Korean] Ministry of Agriculture and Forestry, Seoul, Korea.

Nelson, M. C., K. Kintigh, D. R. Abbott, and J. M. Anderies. 2010. The cross-scale interplay between social and biophysical context and the vulnerability of irrigation-dependent societies: archaeology's long-term perspective. Ecology and Society 15(3): 31. [online] URL: http://www.ecologyandsociety.org/vol15/iss3/ $\underline{\operatorname{art} 31 /}$

Olsson, P., C. Folke, and T. Hahn. 2004. Social-ecological transformation for ecosystem management: the development of adaptive co-management of a wetland landscape in Southern Sweden. Ecology and Society 9(4): 2. [online] URL: http://www. ecologyandsociety.org/vo19/iss4/art2/

Ostrom, E. 1990. Governing the commons: the evolution of institutions for collective action. Cambridge University Press, Cambridge, UK. http://dx.doi.org/10.1017/CBO9780511807763

Ostrom, E. 1996. Crossing the great divide: coproduction, synergy, and development. World Development 24(6):1073-1087. http://dx.doi.org/10.1016/0305-750X(96)00023-X

Ostrom, E. 2005. Understanding institutional diversity. Princeton University Press, Princeton, New Jersey, USA.

Ostrom, E. 2007. A diagnostic approach for going beyond panaceas. Proceedings of the National Academy of Sciences of the United States of America 104(39):15181-15187. http://dx.doi. org/10.1073/pnas.0702288104

Ostrom, E. 2009. A general framework for analyzing sustainability of social-ecological systems. Science 325 (5939):419-22. http://dx.doi.org/10.1126/science.1172133

Ostrom, E., T. Dietz, N. Dolšak, P. C. Stern, S. Stonich, and E. Weber, editors. 2002. The drama of the commons. National Research Council, National Academy Press, Washington, D.C., USA.

Park, J. 2000. A study of "Keumsonggye" in the later Chosun Dynasty. [Title translated from the Korean] Choong Ang University, Seoul, Korea.

Pérez, I., M. A. Janssen, A. Tenza, A. Giménez, A. Pedreño, and M. Giménez. 2011. Resource intruders and robustness of socialecological systems: an irrigation system of Southeast Spain, a case study. International Journal of the Commons 5(2):410-432. [online] URL: http://www.thecommonsjournal.org/index.php/ ijc/article/view/278/220

Poteete, A. R., and E. Ostrom. 2004. Heterogeneity, group size and collective action: the role of institutions in forest management. Development and Change 35(3):435-461. http://dx. doi.org/10.1111/j.1467-7660.2004.00360.x

Poteete, A. R., E. Ostrom, and M. A. Janssen. 2010. Working together: collective action, the commons, and multiple methods in practice. Princeton University Press, Princeton, New Jersey, USA.

$\mathrm{R}$ Development Core Team, 2008. $R$ : a language and environment for statistical computing. R Foundation for Statistical Computing, Vienna, Austria. [online] URL: http://www.R-project.org
Rudel, T. K. 2011. The commons and development: unanswered sociological questions and common property institutions. International Journal of the Commons 5(2):303-318. [online] URL: http://www.thecommonsjournal.org/index.php/ijc/article/view/248/212

Silva, J. A., S. Eriksen, and Z. A. Ombe. 2010. Double exposure in Mozambique's Limpopo River Basin. Geographical Journal 176:6-24. http://dx.doi.org/10.1111/j.1475-4959.2009.00343.x

Walker, B., C. S. Holling, S. R. Carpenter, and A. Kinzig. 2004. Resilience, adaptability and transformability in social-ecological systems. Ecology and Society 9(2): 5. [online] URL: http://www. ecologyandsociety.org/vol9/iss2/art5/

Weiss, A. D. 2001. Topographic position and landforms analysis. ESRI International User Conference, San Diego, California, USA, July 9-13. [online] URL: http://www.jennessent.com/ downloads/tpi-poster-tnc 18x22.pdf

Westley, F. 1995. Governing design: the management of social systems and ecosystems management. Pages 391-427 in L. H. Gunderson, C. S. Holling, and S. S. Light, editors. Barriers and bridges to the renewal of ecosystems and institutions. Columbia University Press, New York, New York, USA.

Wollenberg, E., M. Moeliono, G. Limberg, R. Iwan, S. Rhee, and M. Sudana. 2006. Between state and society: local governance of forests in Malinau, Indonesia. Forest Policy and Economics 8 (4):421-433. http://dx.doi.org/10.1016/j.forpol.2005.08.012

Wunder, S., B. Campbell, P. G. H. Frost, J. A. Sayer, R. Iwan, and L. Wollenberg. 2008. When donors get cold feet: the community conservation concession in Setulang (Kalimantan, Indonesia) that never happened. Ecology and Society 13(1): 12. [online] URL: http://www.ecologyandsociety.org/vol13/iss1/art12/

Young, O., F. Berkhout, G. Gallopin, M. Janssen, E. Ostrom, and S. Van der Leeuw. 2006. The globalization of socio-ecological systems: an agenda for scientific research. Global Environmental Change 16(3):304-316. http://dx.doi.org/10.1016/j.gloenvcha.2006.03.004 
Appendix 1. Forest growth in Geumsan from 1976 to 2010.

The overall forest cover of Geumsan, South Korea increased by a factor of 13.4 between 1976 and 2010 .

Table A.1. Trends in forest cover in Geumsan from 1976 to 2010 (Source: KFS 2013, KNSO 2013).

\begin{tabular}{l|c}
\hline \multicolumn{1}{c|}{ Year } & Growing stock \\
$\left(\mathrm{m}^{3}\right)$
\end{tabular}

\section{Model selection}

We studied the factors determining cooperative transformation by means of multivariate logisticregression models. Contextual factors included two factors (spatial extent of villages and size of the resource system), four continuous variables (number of villages, existence of tenant fees, ratio of crossinstitutional links, and topographic location of villages), and one dichotomous variable (terrain of resource system). Our dependent variables (type of transformation) is dichotomous ( 1 if cooperative transformation and 0 if non-cooperative transformation). See Table A.2 for the values given to each variable.

Table A.2. Values of independent variables.

\begin{tabular}{ll}
\hline Variables & Values \\
\hline Existence of tenant fees & 1: annual tenant fees were collected \\
& 0 : otherwise \\
Number of villages & Continuous. Range: $1-39$ \\
Ratio of cross-institutional links & Continuous. Range: $0-1$ \\
Spatial extent of villages & $0:$ one village is involved; \\
& 1: multiple villages are involved but all are situated within one sub- \\
district & 2: multiple villages are involved and are situated over multiple sub- \\
districts & $0: 1-10$ hectares \\
Size of resource system & 2: $11-100$ hectares \\
& $1:$ considerable dry-field farming exists \\
Terrain of resource system & $0:$ otherwise \\
& Continuous. Range: $0.05-0.61$ \\
\hline
\end{tabular}

We used a model selection approach (Johnson and Omland 2004) to determine which sets of combinations of factors better explain cooperative transformation. We applied the Akaike Information 
Criterion (AIC) method to compare the fits of all possible combinations of explanatory variables (Burnham and Anderson 2002). AIC is calculated for a suite of models and the best-fitting model has the smallest AIC. The absolute size of the AIC is unimportant; instead the difference in AIC values between the best fitting model and the others models $\left(\Delta_{i}\right)$ indicates the relative support for the models. In order to compare models, we calculate Akaike weights $(w)$ as the probability that a model would be selected as the best fitting model if the data were collected again under identical circumstances (Burnham and Anderson, 2002):

$$
w_{i}=\frac{\exp \left(-0.5 * \Delta_{i}\right)}{\sum_{r=1}^{R} \exp \left(-0.5 * \Delta_{r}\right)}
$$

Where $w_{i}$ is the Akaike weights for model $i ; \Delta_{i}$ is the different between the AIC of the best fitting model and that of model $i$. The numerator is the relative likelihood of the model $i$. The denominator calculates the sum of the relative likelihoods for all candidate models.

For the set of models, Akaike weights sum to 1. A model whose Akaike weight is close to 1 is unambiguously supported by the data (Burnham and Anderson 2002). We consider as plausible models those with Akaike weights that are within $10 \%$ of the highest weight. We also calculated the relative variable importance as the sum of Akaike weights over all models including the explanatory variable. The relative variable importance is the probability that, of the variables considered, a certain variable is in the best approximating model. We calculated the model averaged estimates weighted by its Akaike weight (Burnham and Anderson 2002). Model-averaged parameter estimates are only calculated for those independent variables that are included in the confidence set of models.

All analyses were conducted using the R Project (R Development Core Team, 2008) for Statistical Computing package, particularly applying the package MuMln (Bartón 2012). 